\title{
Pemasaran Komposter Pengolahan Sampah Organik Menjadi Pupuk Pada Kelompok Usaha Tebe Komposter
}

\author{
Ade Ruly Sumartini ${ }^{1 *}$, Ni Made Vita Indriyani ${ }^{2}$, I Wayan Gde Yogiswara Darma P. ${ }^{3}$ iD \\ 1,2,3 Fakultas Ekonomi dan Bisnis Universitas Warmadewa, Indonesia \\ *Corresponding author: aderuly81@gmail.com
}

\begin{abstract}
Abstrak
Pencemaran lingkungan banyak disebabkan oleh tumpukan sampah yang tidak diolah dan dibuang begitu saja. Untuk mengatasi permasalahan mengenai penumpukan sampah, maka dibutuhkan upaya pengolahan sampah menjadi produk baru yang bernilai ekonomis. Salah satu upaya dalam mengurangi timbunan sampah rumah tangga yakni menjadikan sampah sebagai pupuk kompos, dalam program pengabdian kepada masyarakat. Tujuan dari pelaksanaan program pengolahan sampah yakni untuk mengurangi timbunan sampah di lingkungan sreta meningkatkan hasil jumlah pengahasilan kelompok usaha pengolahan sampah. Program Pengabdian kepada masyarakat ini dilaksanakan dalam 2 tahap yakni tahap persipan dan tahap pelaksanaan yang dilakukan dalam 3x pertemuan. Adapun program yang dijalankan dalam kegiatan ini adalah menyusun sistem pemasaran produk, mendesain serta membuat label/brand, melakukan pengadaan bahan baku, penyusunan buku laporan keungan, dan pelatihan penerapan tata kelola perusahaan. Hasil dari program pengabdian kepada masyarakat ini menunjukkan bahwa terdapat peningkatan pengahasilan serta kemampuan kelompok usaha tebe komposter dalam mengolah sampah menjadi pupuk organik.
\end{abstract}

Kata Kunci: Pengabdian Masyarakat, Pengelolaan Sampah

\section{Abstract}

A lot of environmental pollution is caused by piles of garbage that are not processed and thrown away. To overcome the problem of waste accumulation, efforts are needed to process waste into new products that have economic value. One of the efforts to reduce the accumulation of household waste is to make waste as compost, in a community service program. The purpose of the implementation of the waste management program is to reduce the accumulation of waste in the environment as well as to increase the total income of the waste processing business group. This community service program is carried out in 2 stages, namely the preparation stage and the implementation stage which is carried out in 3 meetings. The programs carried out in this activity are compiling a product marketing system, designing and creating labels/brands, procuring raw materials, preparing financial report books, and training on the implementation of corporate governance The results of this community service program show that there is an increase in income and the ability of the Tebe composter business group to process waste into organic fertilizer

Keywords: Community Service, Waste Management

\section{INTRODUCTION}

Sampah merupakan produk sampingan dari aktivitas masyarakat yang merupakan hasil sisa produk yang tidak digunakan atau sudah tidak dapat digunakan kembali (Agus et al., 2019). Sampah padat atau solid waste dapat dibagi menjadi 2 yakni sampah organik dan sampah non organik (Indriyanti et al., 2015). Sampah organik merupakan sampah yang dapat diurai dan berasal dari sisa-sisa makanan, daun, dan bahan organik lainnya, sedangkan sampah non-organik merupakan sampah yang tidak dapat diurakan seperti kaca dan plastik, namun sampah non-oragik ini masih dapat didaur ulang menjadi barang yang memiliki nilai ekonomis (Widawati et al., 2014).

Sampah merupakan salah satu permasalahan yang membutuhkan perhatian khusus, hal ini karena sampah telah menjadi persoalan nasional (Darmawan et al., 2020; Kristina et al., 2020). Kegagalan dalam pengelolaan sampah berimbas pada menurunnya kualitas

$\begin{array}{ll}\text { History: } & \\ \text { Received } & \text { : April 02, } 2021 \\ \text { Revised } & \text { : April 09, } 2021 \\ \text { Accepted } & \text { : May 16, } 2021 \\ \text { Published } & \text { : May 25, } 2021\end{array}$


kesehatan warga masyarakat, merusak estetika kota, dan dalam jangka panjang dapat mempengaruhi arus investor ke daerah (Yogiesti et al., 2010). Pembuangan sampah yang selama ini banyak dilakukan adalah dengan ditumpuknya dipinggir jalan, yang kemudian diambil oleh petugas kebersihan. Namun hal ini tidak berlaku bagi masyarakat yang memiliki tempat tinggal jauh dari jangkauan petugas kebersihan, dimana pada kasus ini terdapat banyak masyarakat yang membuang sampah kesungai, menumpuk sampah begitu saja atau dibakar. Menumpuknya sampah di suatu daerah disebabkan karena masyarakat yang cenderung masih memahami sampah sebagai barang yang tidak diinginkan sehingga harus segera dibuang (Krisnani et al., 2017; Styana et al., 2019). Persepsi masyarakat mengenai sampah inilah yang menjadikan sampah hanya berpindah tempat dan akhirnya menumpuk pada satu tempat saja, misalnya tempat pembuangan akhir (TPA) (Masyrukan., 2016).

Data Bank Dunia menyebutkan, produksi sampah padat secara di Indonesia mencapai 151.921 ton per hari (Wijayanti \& Sasongko, 2018). Hal ini berarti, setiap penduduk Indonesia membuang sampah padat rata-rata $0,85 \mathrm{~kg}$ per hari. Data yang sama juga menyebutkan, dari total sampah yang dihasilkan secara nasional, hanya $80 \%$ yang berhasil dikumpulkan dan sisanya terbuang mencemari lingkungan (Nuryosuwito et al., 2020). Pengelolaan sampah di suatu daerah akan membawa pengaruh bagi masyarakat maupun lingkungan daerah itu sendiri, baik itu berupa pengaruh postif ataupun negatif (Nuswari, 2006). Pengaruh yang ditimbulkan dari adanya sampah ini sangatlah penting bagi kehidupan manusia seperti dalam estetika lingkungan menjadi kurang sedap dipandang mata, proses pembusukan sampah oleh mikroorganisme akan menghasilkan gas-gas tertentu yang menimbulkan bau busuk, pembakaran sampah dapat menimbulkan pencemaran udara dan bahaya kebakaran yang lebih luas, pembuangan sampah ke dalam saluran pembuangan air akan menyebabkan aliran air terganggu dan saluran air akan menjadi dangkal. Terdapat berbagai macam upaya yang dapat dilakukan untuk mengatasi masalah penumpukan sampah di lingkungan sekitar, salah satunya adalah membentuk usaha baru yang memanfaatkan sampah sebagai bahan baku utama untuk menghasilkan produk yang bernilai guna serta mampu menjaga kelestarian lingkungan dengan mengusahakan limbah menjadi hal yang lebih bermanfaat (Jalaluddin et al., 2017; Monita et al., 2017). Salah satu produk yang dihasilkan dari proses daur ulang sampah adalah pupuk organik. Pupuk organik merupakan suatu produk yang dihasilkan dari pengolahan sampah organik yang dapat digunakan untuk menyuburkan tanaman dan mengurangi penggunaan pupuk kimia.

Pupuk organik diolah menggunakan alat-alat komposter yang bersumber energi otomatis, misalnya energi listrik dan bahan bakar, namun proses tersebut harus melalui tahaptahap tertentu untuk menghasilkan kompos. Tahap tersebut tentunya harus menyita waktu dan memerlukan biaya untuk membeli energi/bahan bakar tersebut. Sehingga masyrakat enggan untuk mengolah sampah organik menjadi pupuk organik. Hal ini sejalan dengan hasil wawancara dengan kelompok usaha Tebe Komposter yang terletak di kabupaten Badung. Berdasarkan hasil wawancara diketahui bahwa selain proses pengolahan yang cukup lama, pengelolaan manajemen usaha komposter pengolahan sampah menjadi pupuk organik juga mengalami kendala di berbagai aspek lainnya seperti: 1) belum adanya manajemen pengolahan sampah menjadi pupuk organik karena kurang pemahaman mengenai strategi produksi dan pemasaran, 2) Belum adanya label/brand, 3) Tidak adanya tata cara pembukuan/catatan harian terkait produksi, pendapatan, biaya, laba rugi, sehingga benarbenar tidak mengetahui dengan jelas kondisi dan posisi keuangan, 4) Mitra belum mengetahui tata kelola perusahaan yang baik dalam menentukan harga pokok produksi, 5) Keterbatasan untuk pengadaan bahan baku pembuatan tebe komposter. Adapun upaya yang dapat dilakukan untuk mengatasi permasalahan diatas yakni dengan menyusun sistem pemasaran produk, mendesain serta membuat label/brand, melakukan pengadaan bahan baku, penyusunan buku laporan keungan, dan pelatihan penerapan tata kelola perusahaan. Proses 
pemecahan masalah ini dilakukan melalui program Pengabdian Kepada Masyarakat oleh tim PKM Universitas Warmadewa, dengan tujuan untuk membantu kelompok usaha tebe komposter dalam mengolah serta memasarkan produk pupuk organik

\section{MATERIALS AND METHODS}

Pelaksanan program pengabdian masyarakat oleh tim PKM Universitas Warmadewa dilakukan bersama 1 kelompok mitra yakni kelompok usaha tebe komposter yang berada di wilayah kabupaten Badung. Kegiatan pengabdian masyarakat ini dilakukan dalam 2 tahap yakni tahap persiapan yang dimulai pada tanggal 1 dan 17 April 2021 dan tahap pelaksanaan pada tanggal 8 Mei 2021. Pada tahap persiapan tim PKM melaksanakan koordinasi dengan pihak kampus dan mitra, setelah program disetujui maka tahap persipan dilanjutkan dengan mempersiapkan berbagai keperluan yang dibutuhkan. Selanjutnya pada tahap pelaksanaan dilakukan proses pelaksanaan program dengan mengajak 3 orang narasumber dan melakukan berbagai pelatihan kepada mitra. Tahap pelaksanaan dilakukan dalam 3 kali pertemuan

Terdapat 5 program yang dijalankan dalam program pengabdian kepada masyarakat ini, yang terdiri dari pelatihan pemasaran produk, pembuatan label/brand, pengadaan bahan baku, pelatihan pembuatan pembukuan atau laporan keuangan, serta pelatihan penerapan tata kelola perusahaan. Pada program pertama yakni program pelatihan pemasaran produk dilakukan memberikan pelatihan tentang strategi pemasaran, membantu dalam membuatkan website dan akun media sosial seperti facebook dan instagram serta melakukan pendampingan dalam penggunaannya, dengan tujuan untuk memperluas jangkauan pemasaran produk. Pada program kedua, yakni pembuatan label/brand dilakukan dengan Membantu mitra dalam pembuatan label. Berdasarkan survei awal, label yang digunakan telah ada namun masih belum bisa dikenal oleh masyarakat Sehingga tim pengusul akan melakukan desain ulang label Tebe Komposter.

Ketiga, yakni program pengadaan bahan baku dilakukan dengan membantu mitra dalam pengadaan bahan baku dan peralatan komposter dengan memberikan investasi modal maupun peralatan dengan tujuan untuk meningkatkan jumlah serta kualitas produksi pupuk organik. Keempat, yakni program pembuatan pembukuan atau laporan keuangan dilakukan melalui pendekatan individual. Pendekatan individual ini diawali dengan menggali pemahaman mitra berkaitan dengan pembukuan. Setelah menggali pemahaman mitra mengenai pembukuan, kemudian dilanjutkan dengan memberikan materi dan pemahaman seperti apa bentuk dari buku keuangan sederhana serta apa saja isi dari buku keuangan sederhana. Kemudian, mitra diajak mencari tahu hal apa saja yang dibutuhkan jika ingin mengetahui berapa laba bersih yang dihasilkan dan berapa besar riilnya biaya yang dihabiskan serta membuat buku laporan keuangan sederhana. Setelah memberikan pemahaman, mitra kemudian diberikan sebuah buku kosong untuk diajak menyusun buku laporan keuangan sederhana. Dan program yang kelima yakni pelatihan penerapan tata kelola perusahaan dilakukan dengan memberikan penyuluhan tentang penerapan tata kelola perusahaan. Tim pengusul akan memberikan penjelasan dan pendampingan dalam menentukan strategi produksi. Tim pengusul juga akan memberikan penyuluhan bagaimana caranya agar tenaga kerja yang dimiliki oleh mitra mau bekerja maksimal lagi, dengan tujuan untuk mengembangkan usaha yang dijalankan

\section{RESULTS AND DISCUSSION}

Pelaksanaan kegiatan pengabdian kepada masyarakat dilakukan dalam 2 tahap yakni tahap persiapan dan tahap pelaksanaan. Pada tahap persiapan dilakukan proses koordinasi bersama pihak kampus dan koordinasi bersama mitra kegiatan. Berdasarkan hasil koordinasi dengan phak mitra, didapatkan informasi bahwa terdapat berbagai macam kendala yang dialami selama proses pengolahan sampah oragnik menjadi pupuk organik. Adapun 
permasalahan tersebut terdiri dari 1) belum adanya manajemen pengolahan sampah menjadi pupuk organik karena kurang pemahaman mengenai strategi produksi dan pemasaran, 2) Belum adanya label/brand, 3) Tidak adanya tata cara pembukuan/catatan harian terkait produksi, pendapatan, biaya, laba rugi, sehingga benar-benar tidak mengetahui dengan jelas kondisi dan posisi keuangan, 4) Mitra belum mengetahui tata kelola perusahaan yang baik dalam menentukan harga pokok produksi, 5) Keterbatasan untuk pengadaan bahan baku pembuatan tebe komposter.

Berdasarkan permasalahan tersebut, disusunlah 5 program pengabdian kepada masyarakat yang terdiri dari menyusun sistem pemasaran produk, mendesain serta membuat label/brand, melakukan pengadaan bahan baku, penyusunan buku laporan keungan, dan pelatihan penerapan tata kelola perusahaan. Setelah program PKM disepakati, kegiatan dilanjutkan dengan menyepakati jadwal pelaksanaan kegiatan dengan peserta pelatihan sehingga peserta pelatihan dapat mengatur waktu kegiatannya dan kegiatan dapat berlangsung sesuai rencana dan dari segi waktu dapat efisien dan menyesuaikan dengan aktifitas peserta. Disepakati dalam pertemuan tersebut pelatihan akan dimulai pada tanggal 8 Mei 2021.

Tahap pelaksanaan program dilakukan sebanyak 3x pertemuan. Pada pertemuan pertama dilaksanakan kegiatan ceramah dengan materi pelatihan pembuatan pembukuan. Kegiatan ceramah pada pertemuan pertama mendatangkan 3 orang narasumber yang terdiri dari 1) Ade Ruly Sumartini, S.E.,M.M. yang menyajikan materi mengenai strategi pemasaran dan memberikan masukan mengenai pembaharuan label, 2) Ni Made Vita Indriyani, S.E., M.Si., menyajikan materi mengenai Kebijakan dan pentingnya proses pembukuan secara terstruktur menggunakan sistem akuntansi, dan 3) Ni Made Vita Indriyani, S.E., M.Si dan I Wayan Gde Yogiswara Darma Putra, S.E., M.SI. menyajikan materi mengenai Kebijakan dan pentingnya pengelompokan biaya serta strategi penggunaan biaya. Hasil dari pelaksanaan kegiatan ini menunjukkan bahwa terdapat peningkatan pemahaman kelompok usaha tebe komposter mengenai tata cara menyusun pembukuan, pengelolaan keuangan, dan penyusunan label produk.

Selanjutnya pada pertemuan kedua, kelompok usaha tebe komposter diberikan pelatihan penggunaan sistem akuntansi berupa excel dan sistem strategi pemasaran melalui media sosial. Peserta pelatihan dituntun oleh instruktur yang berasal dari Dosen di Program Studi Akuntansi dan Manajemen, Fakultas Ekonomi dan Bisnis, Unwar. Hasil dari pertemuan kedua, yakni adanya peningkatan kemampuan kelompok usaha dalam menggunakan sistem akuntansi serta adanya sosial media kusus yang siap untuk memasarkan produk pupuk organik. Dan pada pertemuan ketiga, mitra diarahkan untuk membuat sendiri pembukuan akuntansi tanpa dituntun oleh instruktur hasilnya dievaluasi dimana letak kekurangannya agar nantinya diperbaiki pada pertemuan berikutnya. Pada pertemuan ini juga diserahkan bantuan 20 unit alat komposter untuk meningkatkan ekonomi mitra.

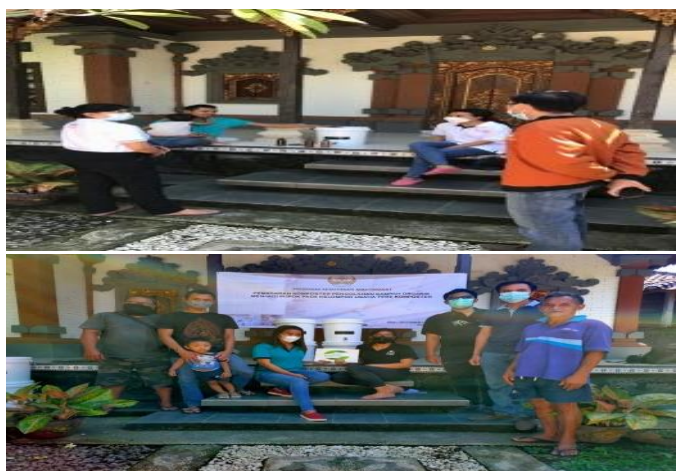

Gambar 1. Pelaksanaan Sosialisasi

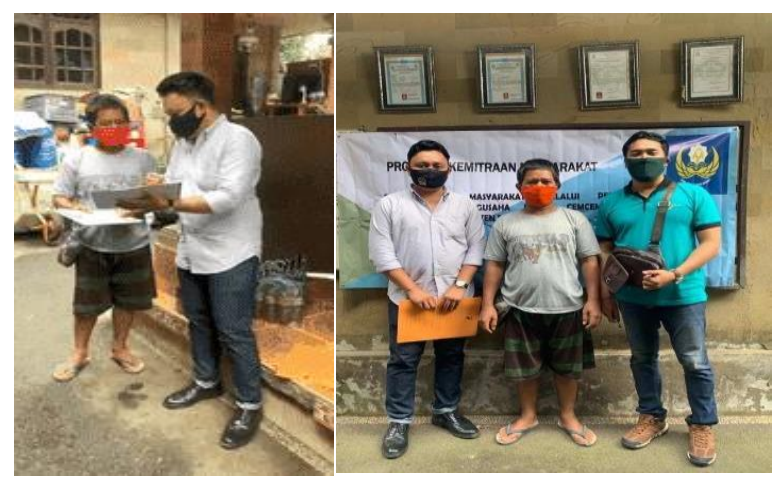

Gambar 2. Pertemuan ke-3 


\section{Pembahasan}

Dalam pengabdian sistem pemasaran produk, serta pembuatan label/brand mitra setelah diberikan penyuluhan tentang sistem pemasaran yang baik dapat lebih memahami dan dapat dipraktekan melalui promosi di media sosial yang telah disediakan. Penggunaan media sosial dalam memasarkan suatu produk akan dapat memberikan hasil yang optimal, hal ini dikarenakan strategi pemasaran mempunyai ruang lingkup yang luas diantaranya adalah strategi dalam menghadapi persaingan, strategi harga, strategi produk, strategi pelayanan dan sebagainya (Achmad et al., 2020; Harinie et al., 2020). Kerjasama berupa pelatihan keterampilan pengelolaan sampah, pembuatan pupuk organik dan pemasarannya dapat meningkatkan keterampilan kelompok pemuda pengangguran di karang taruna sebagai sasaran antara yang strategis dalam membuat produk kompos dimana hasil kegiatan ini adalah berupa pupuk kompos yang berasalah sampah organik dengan nilai tambah ekonomi yang tinggi dan fungsi pemanfaatan potensi setempat (Ibrahim et al., 2017). (Yusrin et al., 2014) menyatakan juga kerjasama dengan mitra tentang pengolahan sampah rumah tangga dimana permasalahan yang terjadi adalah petugas sampah yang sering terlambat datang sehingga terjadi penumpukan sampah. Solusi yang di berikan adalah memberikan ceramah dan praktek manajemen produksi dan usaha, pengembangan modal usaha, dan strategi pemasaran produk dalam rangka menumbuhkan jiwa wirausaha dalam kelompok masyarakat, sehingga terbentuklah kelompok produksi kompos "SAKURA" sehingga mendukung pemasaran alat komposter sebagai alat pengolahan sampah organik.

Ketersediaan bahan baku yang terbatas sudah dapat diatasi dengan bantuan dari tim pengabdian dimana dalam hal ini alat yang dipergunakan berupa tabung yang biasa disebut dengan komposter yang diharapkan dapat membantu pengeloaan sampah rumah tangga yang terjadi. Dalam penerapaannya penggunaan komposter untuk mengolah sampah rumah tangga sangat membantu (Mardwita et al., 2019). Penerapan penggunaan komposter dengan cara mendaur ulang dari tong bekas yang dimodifikasi menjadi alat pembuat kompos dari sampah organik rumah tangga yang dicampur dengan sampah yang sudah jadi menjadi kompos padat dapat mengatasi permasalahan sampah yang terjadi (Elfita \& Suryo, 2020). Hasil dari pengabdian ini juga didukung oleh hasil pengabdian dari (Deviana, 2015) dimana pengomposan merupakan alternative penanganan yang sesuai. Kompos sangat berpotensi untuk dikembangkan mengingat semakin tingginya jumlah sampah organik yang dibuang di tempat pembuangan akhir dan menyebabkan polusi bau dan lepasnya gas metana ke udara. Alat tabung ini dapat mengolah samapah dapur menjadi kompos dengan bantuan bioaktivator. Serta mentargertan agar tabung komposter dapat dipasarkan sebagai salah satu alat pengolahan sampah sederhana (Nugroho et al., 2015). Pelatihan mengenai kebijakan dan pentingnya proses pembukuan secara terstruktur menggunakan sistem akuntansi, pentingnya pengelompokan biaya serta strategi penggunaan biaya juga dilaksanakan dalam pengabdian ini, dimana mitra diharapkan dalam menerapkan sistem pembukuan yang sederhana dalam proses produksinya.

\section{CONCLUSION}

Kegiatan pengabdian kepada masyarakat oleh tim PKM Universitas Warmadewa dilaksanakan bersama 1 kelompok mitra yakni kelompok usaha tebe komposter. Pelaksanaan program dilaksanakan dalam 2 tahap yakni tahap persipan dan tahap pelaksanaan yang dilaksanakan dalam $3 x$ pertemuan. Hasil dari program pengabdian masyarakat ini menunjukkan bahwa peserta pelatihan telah mengikuti pelatihan dengan semangat dan disiplin, pelatihan untuk pembuatan pembukuan dapat dilaksanakan dengan baik dan peserta pelatihan mampu membuat pembukuan tersebut dengan baik dan terstruktur, target luaran dari kegiatan PKM pelatihan pembuatan pembukuan dan pemasaran ini telah diberikan kepada peserta pelatihan. Saran yang dapat diberikan adalah perlu dilakukan pembinaan 
secara berkesinambungan agar peserta pelatihan dapat melaksanakan kegiatan usaha secara berkelanjutan.

\section{REFERENCES}

Achmad, Z. A., Azhari, T. Z., Esfandiar, W. N., Nuryaningrum, N., Syifana, A. F. D., \& Cahyaningrum, I. (2020). Pemanfaatan Media Sosial Dalam Pemasaran Produk Umkm Di Kelurahan Sidokumpul, Kabupaten Gresik. Jurnal Ilmu Komunikasi, 10(1). https://doi.org/https://doi.org/10.15642/jik.2020.10.1.17-31.

Agus, R. N., Oktaviyanthi, R., \& Sholahudin, U. (2019). 3R: Suatu Alternatif Pengolahan Sampah Rumah Tangga. Kaibon Abhinaya: Jurnal Pengabdian Masyarakat, 1(2), 72. https://doi.org/10.30656/ka.v1i2.1538.

Darmawan, I., Ha, M. D., \& Ginting, P. A. (2020). Peningkatan kesadaran akan pengelolaan sampah di desa cinta mulya melalui. Jurnal Aplikasi Ipteks Untuk Masyarakat, 9(4), 249-253. https://doi.org/https://doi.org/10.24198/dharmakarya.v9i4.26624.

Deviana, D. P. (2015). Strategi Pengembangan Usaha Pengelolaan Kompos Di Tpa Bojonegoro. E-Jurnal Unigoro, 1(1). http://ojs.ejournalunigoro.com/index.php/oryza /article/view/10/4.

Elfita, M. Y., \& Suryo, T. (2020). Pengadaan Komposter sebagai Upaya Pengelolaan Sampah di Kelurahan Gedawang Semarang Jawa Tengah. Jurnal Pasopati, 2(2). https://ejournal2.undip.ac.id/index.php/pasopati/article/view/5753.

Harinie, L. T., Hukom, A., \& Juma'eh. (2020). Pendampingan dalam Memasarkan Produk Hasil Usaha UKM melalui Penggunaan Media Sosial di Kabupaten Gunung Mas Kalimantan Tengah. Jurnal Pengabdian Kepada Masyarakat, 04(1), 51-59. https://doi.org/https://doi.org/10.29062/engagement.v4i1.179.

Ibrahim, G. A., Hamni, A., Afriani, L., \& Milyanti, R. (2017). Pemberdayaan Karang Taruna Melalui Pengelolaan Sampah Menjadi Pupuk Kompos Organik Di Desa Sidomulyo. Semnas IIB Darmajaya, 11-25. https://jurnal.darmajaya.ac.id/index.php/PSND/ article/view/854/524.

Indriyanti, D., Banowati, E., \& Margunani. (2015). Pengolahan Limbah Organik Sampah Pasar Menjadi Kompos. Jurnal Abdimas, 19(1). https://tatakota.ub.ac.id/index. php/tatakota/article/view/113/110.

Jalaluddin, J., ZA, N., \& Syafrina, R. (2017). Pengolahan Sampah Organik Buah- Buahan Menjadi Pupuk Dengan Menggunakan Effektive Mikroorganisme. Jurnal Teknologi Kimia Unimal, 5(1), 17. https://doi.org/10.29103/jtku.v5i1.76.

Krisnani, H., Humaedi, S., Fedryansyah, M., Asiah, D. H. S., Basar, G. G. K., Sulastri, S., \& Mulyana, N. (2017). Perubahan Pola Pikir Masyarakat Mengenai Sampah Melalui Pengolahan Sampah Organik Dan Non Organik Di Desa Genteng, Kecamatan Sukasari, Kab. Sumedang. Jurnal Penelitian Dan PPM, 4(2), 281-289. https://journal.unpad.ac.id/prosiding/article/view/14345/6925.

Kristina, N. M. R., Darma, I. G. K. I. P., \& Ratnaningtyas, H. (2020). Pengelolaan Timbulan Sampah Untuk Menjaga Citra Industri Pariwisata Pada Daya Tarik Wisata di Bali. Jurnal Ilmiah Pariwisata, 25(3). https://doi.org/https://doi.org/10.30647/jip.v25i3.1351.

Mardwita, E. S. Y., Atikah, A. M., \& Ariani, D. (2019). Pembuatan Kompos Dari Sampah Organik Menjadi Pupuk Cair Dan Pupuk Padat Menggunakan Komposter. Jurnal Ilmiah Pengabdian Kepada Masyarakat, 1(2), 80-83. https://doi.org/10.32502/suluh\%20abdi. v1i2.2295.

Masyrukan., N. A. dan. (2016). Penanganan Sampah Organik dengan Bak Sampah 
Komposter di Dusun Susukan Kelurahan Susukan Kecamatan Susukan Kabupaten Semarang. WARTA, Volume 19.

Monita, L., Sutjahjo, S. H., Amin, A. A., \& Fahmi, M. R. (2017). Pengolahan Sampah Organik Perkotaan Menggunakan Larva Black Soldier Fly (Hermetia illucens). Jurnal Pengelolaan Sumberdaya Alam Dan Lingkungan (Journal of Natural Resources and Environmental Management), 7(3), 227-234. https://doi.org/10.29244/jps1.7.3.227234.

Nugroho, F. S., Prihardiyan, H. E., Mawasid, F. P., Wicaksono, N., \& Herasmaya, M. R. (2015). Tabung Biru Komposter Sampah Dapur Rumah Tangga. https://eprints.uns.ac.id/id/eprint/27104\%0A.

Nuryosuwito, Rosydi, M. A. I., \& Istiqlaliyah, H. (2020). Pemanfatan Sampah Plastik Jenis Hdpe Menjadi Bahan Bakar Alternatif Proses Pyrolysis. Jurnal Mesin Nusantara, 3(2), 92-101. https://doi.org/https://doi.org/10.29407/jmn.v3i2.15573.

Nuswari, T. (2006). Buku Panduan Mengelola Sampah Rumah Tangga Dengan Prinsip 4R . Pekanbaru, Kementrian Lingkungan Hidup RI. PT. Penerbit Erlangga, Jl. H Baping No 100 Ciracas, Jakarta.

Styana, U. I. F., Hindarti, F., Ardito, M. N., \& Cahyono, M. S. (2019). Penerapan Teknologi Pengolahan Sampah Plastik menjadi Bahan Bakar Minyak untuk Mengatasi Masalah Sampah di Kota Bandung. Jurnal Pengabdian Masyarakat Bidang Teknologi, 2(1). https://ejournals.itda.ac.id/index.php/KACANEGARA/article/view/399.

Widawati, E., Tanudjaja, H., Iskandar, I., \& Budiono, C. (2014). Kajian potensi pengolahan sampah (Studi Kasus: Kampung Banjangsari). Jurnal Metris, 15, 119-126. http://ojs.atmajaya.ac.id/index.php/metris/article/view/78.

Wijayanti, W., \& Sasongko, M. N. (2018). Pengaruh campuran sampah plastik dengan katalis alam terhadap hasil produk pyrolisis. Jurnal Rekayasa Mesin, 9(2), 85-91. https://doi.org/https://doi.org/10.21776/ub.jrm.2018.009.02.3.

Yogiesti, V., Hariyani, S., \& Sutikno, F. R. (2010). Pengelolaan Sampah Terpadu Berbasis Masyarakat Kota Kediri. Jurnal Tata Kota Dan Daerah, 2(0341), 95-102. https://tatakota.ub.ac.id/index.php/tatakota/article/view/113/110.

Yusrin, A., Hidayati, \& Wibowo, R. E. (2014). Iptek Bagi Masyarakat (Ibm)Rw Iv Dan Rw Vi Kelurahan Krapyak Semarang Dalam Pengolahan Sampah Organik Menjadi Pupuk Organik. Prosiding Seminar Nasional. https://jurnal.unimus.ac.id/index.php/psn 12012010/article/view/1241. 